\title{
Gambaran Tekanan Darah, Indeks Massa Tubuh, dan Aktivitas Fisik pada Mahasiswa Kedokteran Umum Angkatan Tahun 2014
}

\author{
${ }^{1}$ Yoel P. Abaa \\ ${ }^{2}$ Hedison Polii \\ ${ }^{3}$ Pemsi M. Wowor
}

\author{
${ }^{1}$ Program Studi Pendidikan Dokter Fakultas Kedokteran Universitas Sam Ratulangi Manado \\ ${ }^{2}$ Bagian Fisiologi Fakultas Kedokteran Universitas Sam Ratulangi \\ ${ }^{3}$ Bagian Farmakologi dan Terapi Email:jhoel.abaa@yahoo.co.id
}

\begin{abstract}
This study was aimed to obtain the profile of blood pressure and factors that could influence blood pressure of Medical Faculty students of Sam Ratulangi University of Manado year 2014. This was a descriptive study with a cross sectional design. Study population consisted of 75 students year 2014. Respondents were 48 students obtained by using simple random sampling technique. The results showed that most respondents had normal systolic pressure (41 respondents; 85.4\%), normal diastolic pressure (44 respondents; $91.6 \%$ ), normal body mass index (27 respondents; $56.2 \%$ ), and low physical activity (43 respondents; $89.6 \%$ ). Conclusion: Most students had normal systolic blood pressure, normal diastolic blood pressure, normal BMI, and low physical activity.
\end{abstract}

Keywords: blood pressure, body mass index, physical activity

\begin{abstract}
Abstrak: Penelitian ini bertujuan untuk mengetahui gambaran tekanan darah dan faktor-faktor yang dapat memengaruhi tekanan darah mahasiswa Fakultas Kedokteran Universitas Sam Ratulangi Manado angkatan tahun 2014. Jenis penelitian ialah deskriptif dengan desain potong lintang. Populasi penelitian ialah seluruh mahasiswa angkatan 2014 Fakultas Kedokteran Universitas Sam Ratulangi yang berjumlah 75 orang. Terdapat 48 responden diperoleh dengan teknik simple random sampling. Hasil penelitian mendapatkan bahwa tekanan sistolik terbanyak ialah kategori normal (41 responden; 85,4\%) dan tekanan diastolik terbanyak ialah kategori normal (44 responden; 91,6\%). Indeks massa tubuh terbanyak ialah kategori normal (27 responden; 56,2\%). Tingkat aktivitas fisik responden terbanyak yaitu aktifitas fisik ringan 43 orang $(89,6 \%)$. Simpulan: Pada penelitian ini sebagian besar mahasiswa memiliki tekanan darah sistolik kategori normal, tekanan darah diastolik kategori normal, IMT normal, dan aktivitas fisik ringan.
\end{abstract}

Kata kunci: tekanan darah, indeks massa tubuh, dan aktivitas fisik

Hipertensi merupakan istilah yang digunakan untuk seseorang yang mengalami tekanan darah arteri di atas rata-rata. Jika dalam keadaan istirahat, tekanan darah arteri seseorang di atas $110-120 \mathrm{mmHg}$ dalam dua kali pengukuran maka dapat dianggap orang tersebut sudah mengalami hipertensi.

Banyak orang yang tidak sadar bahwa sebenarnya telah mengidap hipertensi, dan nanti disadari setelah mengalami gejalagejala yang sudah lumayan parah. Hiper- tensi ini berbahaya dan memiliki efek letal dikarenakan kinerja jantung yang berlebihan berpotensi untuk menimbulkan penyakit jantung koroner dan kongestif yang dapat menimbulkan serangan jantung tekanan yang tinggi pada pembuluh darah otak dapat menyebabkan ruptur pada pembuluh darah otak yang berujung pada stroke, tekanan yang tinggi mampu menyebabkan perdarahan ginjal yang selanjutnya berujung pada kerusakan 
beberapa area ginjal dan juga gangguan vaskuler perifer. ${ }^{1}$

World Health Organization (WHO) tahun 2012, menjelaskan bahwa hipertensi memberikan kontribusi untuk hampir 9,4 juta kematian akibat penyakit kardiovaskuler setiap tahun. Hal ini juga meningkatkan risiko penyakit jantung koroner (PJK) sebesar $12 \%$ dan meningkatkan risiko stroke sebesar 24\%. Data Global Status Report on Noncommunicable Diseases 2010 dari WHO, menyebutkan 40\% negara ekonomi berkembang memiliki penderita hipertensi, sedangkan negara maju hanya 35\%. Departemen Kesehatan Republik Indonesia tahun 2013, menyatakan bahwa di Kawasan Asia Tenggara terdapat $36 \%$ orang dewasa yang menderita hipertensi dan telah membunuh 1,5 juta orang setiap tahunnya. Jumlah penderita hipertensi akan terus meningkat tajam, diprediksikan pada tahun 2025 sekitar $29 \%$ atau sekitar 1,6 miliar orang dewasa di seluruh dunia menderita hipertensi. ${ }^{2,3}$

Menurut hasil Riset Kesehatan Dasar (Riskesdas) Indonesia tahun 2013 prevalensi hipertensi di Indonesia yang didapat melalui pengukuran pada umur $\geq 18$ tahun sebesar $25,8 \%$, tetapi yang terdiagnosis oleh tenaga kesehatan atau riwayat minum obat hanya sebesar 9,5\%. Hal ini menandakan bahwa sebagian besar kasus hipertensi di masyarakat belum terdiagnosis dan terjangkau pelayanan kesehatan. Hipertensi juga merupakan penyebab kematian ke-3 di Indonesia pada semua umur dengan proporsi kematian 6,8\%. Profil Kesehatan Provinsi Sulawesi Utara tahun 2014, penderita penyakit hipertensi seluruhnya mencapai 31377 orang. Di Kota Manado, jumlah penderita hipertensi sebanyak 3256 orang, dan Kota Manado menepati urutan ke-4 dari 15 kota dan kabupaten di Sulawesi Utara yang memiliki penderita hipertensi terbanyak. ${ }^{3,4}$

Selain faktor genetik, usia dan jenis kelamin yang dikaitkan dengan tekanan darah tinggi dan gaya hidup juga sering menjadi faktor risiko penting bagi timbulnya hipertensi pada seseorang. Beberapa di antaranya ialah kebiasaan makan seperti konsumsi lemak dan tinggi garam, kegemukan atau makan secara berlebihan. Gaya hidup yang tidak sehat seperti minumminuman mengandung alkohol, stres, emosional dan kurangnya aktivitas fisik yang dapat meningkatkan risiko kelebihan berat badan juga menjadi faktor resiko hipertensi. ${ }^{5}$

Penelitian ini bertujuan untuk mendapatkan gambaran tekanan darah dan faktor-faktor yang berhubungan dengan tekanan darah pada mahasiswa Fakultas Kedokteran angkatan 2014 Universitas Sam Ratulangi Manado.

\section{METODE PENELITIAN}

Jenis penelitian ini ialah deskriptif dengan desain potong lintang, yang dilakukan pada bulan Maret 2017 - Agustus 2017 di Kampus Fakultas Kedokteran Universitas Sam Ratulangi. Populasi seluruh mahasiswa angkatan 2014 yang berjumlah 75 orang dan responden berjumlah 48 orang; 14 responden tidak bersedia mengikuti penelitian. Besar sampel ditentukan dengan menggunakan rumus Slovin.

\section{HASIL PENELITIAN}

Hasil pengumpulan data, karakteristik responden berdasarkan jenis kelamin, usia, aktifitas fisik, IMT, dan tekanan darah responden dapat dilihat pada tabel berikut:

Tabel 1. Distribusi responden berdasarkan jenis kelamin

\begin{tabular}{ccc}
\hline $\begin{array}{c}\text { Jenis } \\
\text { kelamin }\end{array}$ & n & \% \\
\hline Perempuan & 32 & 66,7 \\
Laki-laki & 16 & 33,3 \\
Jumlah & 48 & 100 \\
\hline
\end{tabular}

Tabel 2. Distribusi responden berdasarkan usia

\begin{tabular}{ccc}
\hline Usia & $\mathbf{n}$ & $\mathbf{\%}$ \\
\hline 19 & 3 & 6,3 \\
20 & 28 & 58,3 \\
21 & 17 & 35,4 \\
Jumlah & 48 & 100 \\
\hline
\end{tabular}


Tabel 3. Distribusi responden berdasarkan aktivitas fisik selama 7 hari

\begin{tabular}{ccc}
\hline Aktivitas fisik & n & \% \\
\hline Ringan & 43 & 89,6 \\
Sedang & 5 & 10,4 \\
Jumlah & 48 & 100 \\
\hline
\end{tabular}

Tabel 4. Distribusi responden berdasarkan IMT

\begin{tabular}{ccc}
\hline IMT & $\mathbf{n}$ & $\mathbf{\%}$ \\
\hline Underweight & 1 & 2,1 \\
Normal & 27 & 56,2 \\
Overweight & 11 & 22,9 \\
Obese I & 6 & 12,5 \\
Obese II & 3 & 6,3 \\
Jumlah & 48 & 100 \\
\hline
\end{tabular}

Tabel 5. Distribusi responden berdasarkan tekanan darah sistolik

\begin{tabular}{lcc}
\hline Tekanan sistolik & Frekuensi & $\begin{array}{c}\text { Persentase } \\
(\mathbf{\%})\end{array}$ \\
\hline Hipotensi & 3 & 6,3 \\
Normal & 41 & 85,4 \\
Prehipertensi & 4 & 8,3 \\
Hipertensi, stage 1 & 0 & 0 \\
Hipertensi, stage 2 & 0 & 0 \\
Total & 48 & 100 \\
\hline
\end{tabular}

Tabel 6. Distribusi responden berdasarkan tekanan darah diastolik

\begin{tabular}{lcc}
\hline Tekanan distolik & Frekuensi & $\begin{array}{c}\text { Persentase } \\
(\mathbf{\%})\end{array}$ \\
\hline Hipotensi & 2 & 4,2 \\
Normal & 44 & 91,6 \\
Prehipertensi & 2 & 4,2 \\
Hipertensi, stage 1 & 0 & 0 \\
Hipertensi, stage 2 & 0 & 0 \\
Total & 48 & 100 \\
\hline
\end{tabular}

\section{BAHASAN}

Tekanan darah merupakan gaya yang diberikan darah terhadap dinding pembuluh darah dan ditimbulkan oleh desakan darah terhadap dinding arteri ketika darah tersebut dipompa dari jantung ke jaringan. Besar tekanan bervariasi tergantung pada pembuluh darah dan denyut jantung. Tekanan darah paling tinggi terjadi ketika ventrikel berkontraksi (tekanan sistolik) dan paling rendah ketika ventrikel berelaksasi (tekan- an diastolik). Faktor-faktor yang memengaruhi tekanan darah diantaranya ialah jenis kelamin, usia, tingkat pendidikan, aktivitas fisik, faktor genetik (keturunan), asupan makan, kebiasaan merokok, dan stres. ${ }^{6,7}$

Hasil penelitian yang dilakukan terhadap mahasiswa angkatan 2014, mendapatkan karakteristik berdasarkan jenis kelamin yang terbanyak ialah perempuan yaitu 32 orang $(45,5 \%)$ sedangkan laki-laki yaitu 16 orang (33,3\%). Prevalensi terjadinya hipertensi pada laki-laki sama dengan perempuan. Berdasarkan penelitian yang dilakukan oleh Wahyuni dan Eksanoto, ${ }^{8}$ perempuan cenderung menderita hipertensi daripada laki-laki. Pada penelitian tersebut sebanyak $27,5 \%$ perempuan mengalami hipertensi, sedangkan untuk laki-laki hanya sebesar 5,8\%. Perempuan akan mengalami peningkatan risiko tekanan darah tinggi (hipertensi) setelah menopause yaitu usia diatas 45 tahun.

Namun perempuan terlindung dari penyakit kardiovaskuler sebelum menopause, salah satunya ialah PJK. Perempuan yang belum mengalami menopause dilindungi oleh hormon estrogen dalam mencegah terjadinya proses aterosklerosis. Efek perlindungan estrogen dianggap sebagai penjelasan adanya imunitas perempuan pada usia premenopause. Pada premenopause perempuan mulai kehilangan sedikit demi sedikit hormon estrogen yang selama ini melindungi pembuluh darah dari kerusakan. Proses ini terus berlanjut dimana hormon estrogen tersebut berubah kuantitasnya sesuai dengan usia perempuan secara alami, yang umumnya mulai terjadi pada perempuan berusia 45-55 tahun. ${ }^{7,8}$

Berdasarkan karakteristik golongan usia, responden terbanyak terdapat pada berusia 20 tahun yaitu 28 orang $(58,3 \%)$ dan yang paling sedikit yaitu golongan usia 19 tahun 3 orang $(6,3 \%)$. Kelompok usia ini merupakan dewasa muda. Dewasa muda adalah tahapan dalam perkembangan kehidupan manusia yang harus dijalani. Masa muda seseorang diawali dengan masa transisi dari masa remaja menuju dewasa muda yang melibatkan eksperimentasi dan 
eksplorasi yang disebut emerging adulthood. Perkembangan dewasa dibagi menjadi 3, yaitu: dewasa muda (young adulthood) dengan usia berkisar antara 20 sampai 40 tahun, dewasa menengah (middle adulthood) dengan usia berkisar antara 40 sampai 65 tahun, dan dewasa akhir (late adulthood) dengan usia mulai 65 tahun ke atas. Menurut penelitian yang dilakukan oleh Khomsan pada tahun 2003, umur merupakan salah satu faktor yang memengaruhi tekanan darah. Semakin tua seseorang maka semakin besar resiko terserang hipertensi. ${ }^{6,9}$

Berat badan lebih dan obesitas sering dihubungkan dengan aktivitas fisik. Hal ini bukan hanya terkait masalah banyaknya mengonsumsi makanan tapi juga kurangnya aktivitas fisik. Hasil penelitian ini mendapatkan tingkat aktivitas fisik responden yang terbanyak yaitu aktivitas fisik ringan 43 orang $(89,6 \%)$ dan yang paling sedikit yaitu aktifitas fisik sedang 5 orang $(10,4 \%)$. Namun, berdasarkan IMT pada penelitian ini, yang paling banyak ialah kategori normal yaitu sejumlah 27 responden $(56,2 \%)$ dan paling sedikit kategori underweight 1 responden $(2,1 \%)$, diikuti obese II 3 responden $(6,3 \%)$ dan obese II yaitu 6 orang (12,5\%). Hasil penelitian ini berbeda dengan hasil penelitian Nuraliah et al. ${ }^{10}$ mengenai aktivitas fisik yang dilakukan oleh penyandang overweight dan obesitas menunjukkan bahwa sebagian besar responden melakukan aktivitas fisik ringan, sedangkan nonobesitas memiliki tingkat aktivitas fisik sedang. Menurut Anggara dan Prayitno, ${ }^{11}$ kurangnya aktifitas fisik meningkatkan risiko menderita hipertensi karena meningkatnya risiko kelebihan berat badan. Orang yang kurang melakukan aktivitas fisik juga cenderung mempunyai frekuensi denyut jantung yang lebih tinggi sehingga otot jantungnya harus bekerja lebih keras pada setiap kontraksi. Makin keras dan sering otot jantung harus memompa, makin besar tekanan yang dibebankan pada arteri. ${ }^{10-12}$

Faktor lain yang dapat memengaruhi tekanan darah ialah tingkat pendidikan. Tingkat pendidikan secara tidak langsung juga memengaruhi tekanan darah. Tingkat pendidikan berpengaruh terhadap gaya hidup yaitu kebiasaan merokok, kebiasaan minum alkohol, dan kebiasaan melakukan aktivitas fisik seperti olahraga. Hasil Riskesdas tahun 2013 dalam Badan Penelitian dan Pengembangan Kesehatan (2013) menyatakan bahwa penyakit hipertensi (tekanan darah tinggi) cenderung tinggi pada pendidikan rendah dan menurun sesuai dengan peningkatan pendidikan. Tingginya risiko terkena hipertensi pada pendidikan yang rendah, kemungkinan disebabkan karena kurangnya pengetahuan seseorang yang berpendidikan rendah terhadap kesehatan dan sulit atau lambat menerima informasi (penyuluhan) yang diberikan oleh petugas sehingga berdampak pada perilaku atau pola hidup sehat. ${ }^{11}$

Beberapa penelitian epidemiologi menyebutkan bahwa obesitas pada remaja dan dewasa muda terjadi karena interaksi antara makan yang banyak dan sedikit aktivitas fisik. Aktivitas fisik menyebabkan terjadinya proses pembakaran energi sehingga semakin banyak beraktivitas semakin banyak energi yang terpakai. Hasil penelitian ini selaras dengan studi yang dilakukan Sherwood et al. ${ }^{13}$ yang menunjukkan bahwa olahraga berkonstribusi pada pencegahan kenaikan berat badan. Demikian juga studi yang dilakukan Jakicic et al. ${ }^{14}$ menunjukkan bahwa perempuan yang memiliki berat badan lebih dan obesitas dapat menurunkan berat badannya dalam jangka panjang dengan tambahan aktivitas fisik 200-300 menit/minggu. ${ }^{12-14}$

Berdasarkan tekanan darah sistolik, yang paling banyak ditemukan ialah kategori normal yaitu sejumlah 41 responden $(85,4 \%)$ dan paling sedikit kategori hipotensi 3 orang $(6,3 \%)$. Walaupun demikian, terdapat 4 responden $(8,3 \%)$ mengalami prehipertensi dan berdasarkan IMT memiliki berat badan lebih dan obesitas. Sama halnya dengan tekanan darah diastolik, walaupun didapatkan 44 responden $(91,6 \%)$ memiliki tekanan darah normal namun terdapat $2(4,2 \%)$ yang mengalami prehipertensi. Hasil 
penelitian ini sejalan dengan hasil penelitian Tooy ${ }^{16} 2013$ yang mendapatkan dari 45 responden penelitian terdapat 38 responden $(70,37 \%)$ memiliki tekanan darah normal dan 16 responden $(29,62 \%)$ mengalami hipertensi. Hasil penelitian ini juga selaras dengan hasil penelitian Yessi et al. ${ }^{17}$ yang melaporkan dari 353 responden remaja, didapatkan $(57,79 \%)$ memiliki tekanan darah normal, $(20,11 \%)$ mengalami prehipertensi, dan $(22,10 \%)$ mengalami hipertensi.

Prehipertensi adalah tekanan sistolik dari 120 ke 139 satuan $\mathrm{mm} \mathrm{Hg}$ atau tekanan diastolik dari $80 \mathrm{ke} 89 \mathrm{~mm} \mathrm{Hg}$. Prehipertensi kemungkinan akan berubah menjadi tekanan darah tinggi (hipertensi) jika seseorang tidak mengubah gaya hidup, seperti untuk mulai berolahraga dan makan makanan sehat. Prehipertensi dan tekanan darah tinggi meningkatkan risiko serangan jantung, stroke dan gagal jantung.

\section{SIMPULAN}

Berdasarkan hasil penelitian terhadap mahasiswa Fakultas Kedokteran Universitas Sam Ratulangi angkatan 2014 dapat disimpulkan bahwa yang terbanyak didapatkan ialah mahasiswa dengan tekanan darah sistolik kategori normal, tekanan darah diastolik normal, IMT normal, dan melakukan aktivitas fisik ringan.

\section{SARAN}

Disarankan bagi mahasiswa Fakultas Kedokteran untuk berperilaku hidup sehat dan mencegah terjadinya masalah-masalah kesehatan khususnya yang berhubungan dengan tekanan darah dan faktor-faktor yang memengaruhinya.

Bagi mahasiswa yang mengalami prehipertensi, diperlukan kesadaran untuk mengurangi konsumsi garam dan membiasakan diri untuk berolahraga guna mencegah terjadinya hipertensi diusia dewasa muda.

Bagi mahasiswa yang obes agar membiasakan diri untuk berolahraga yang teratur dan intensif diwaktu senggang guna mengembalikan berat badan ideal sehingga dapat mencegah terjadinya penyakit- penyakit berbahaya diusia muda yang berhubungan dengan berat badan

Bagi mahasiswa yang memiliki kebiasaan beraktivitas fisik ringan, diupayakan untuk mengubah kebiasaan yang buruk berupa kurangnya gerakan badan sehingga energi yang diperoleh dari makanan tidak diubah menjadi lemak dan bertumpuk dibagian perut dan bagian tubuh lainnya yang dapat berakibat penyakit.

\section{DAFTAR PUSTAKA}

1. Sherwood L. Fisiologi manusia dari sel ke system (6th ed). Jakarta: EGC, 2011.

2. WHO. Measure your blood pressure, reduce your risk. [cited 2017 Aug 3]. Available from: http:www.who.int/ mediacentre/news/releases).pdf. 2012.

3. Kementrian Kesehatan RI. Riset Kesehatan Dasar. Jakarta: Badan Penelitian dan Pengembangan Kesehatan. [cited 2017 Aug 3]. Available from: www. litbang.depkes.go.id.pdf. 2013

4. Dinkes Sulawesi Utara. Data Survey Penyakit Tidak Menular Berbasis Puskesmas di Sulawesi Utara. Dinas Kesehatan Manado, 2014

5. Carlson W. Mengatasi Hipertensi. Bandung: Nuasa Cendekia, 2016.

6. Rosta J. Hubungan asupan energi, lemak dengan status gizi dan tekanan darah geriatri di Panti Wredha Surakarta [Skripsi]. Surakarta: Universitas Muhammadiyah; 2011.

7. Cortas K. Hypertension. Last update May 11 2008. [cited 2015 Jan 10]. Available from: http//:www. emedicine.com.

8. Wahyuni, Eksanoto D. Hubungan tingkat pendidikan dan jenis kelamin dengan kejadian hipertensi di Kelurahan Jagalan di Wilayah Kerja Puskesmas Pucang Sawit Surakarta. Jurnal Ilmu Keperawatan Indonesia. 2013;1(1): 79-85.

9. Papalia DE, Old SW, Feldman RD. Human Development (terjemahan). Jakarta: Kencana, 2008.

10. Nuraliyah, Syam A, Hendrayati. Aktifitas fisik dan durasi tidur pada penderita overweight dan obesitas mahasiswa Universitas Hasanuddin [Skripsi]. Makassar: Universitas Hasanuddin; 2014. 
11. Andriardus M. Hubungan antara pola makan dan aktivitas fisik dengan kejadian berat badan lebih pada remaja. 2011 [cited 2015 Sept 18]. Available from: http://core.ac.uk/ download/pdf/11731 785.pdf

12. Jakicic JM, Marcus BH, Gallagher KI, Napolitano M, Lang W. Effect of exercise duration and intensity on weight loss in overweight, sedentary women: a randomized trial. JAMA. 2003;290:1323-30.

13. Anggara FHD, Prayitno N. Faktor-faktor yang berhubungan dengan tekanan darah di Puskesmas Telaga Murni, Cikarang Barat Tahun 2012 . Program Studi S1 Kesehatan Masyarakat STIKES MH. Thamrin. Jakarta. Jurnal Ilmiah Kesehatan. 2013;5(1):2-25.
14. Goran MI, Sothern M. Handbook of pediatric obesity: etiology, pathophysiology and prevention. USA: CRC Press, Taylor \& Francis Group; 2006.

15. Sherwood NE, Jeffery RW, French SA, Hannan PJ, Murray DM. Predictors of weight gain in the Pound of Prevention study. Int J Obes. 2000; 24:395-403.

16. Tooy R. Gambaran Tekanan Darah Pada Remaja Obese Di Kabupaten Minahasa. Jurnal e-Biomedik (eMB). 2013; Volume 1(2), hal.951-955

17. Yessi M, Huriyanti E, Sunarto Y. Indeks massa tubuh dan aktivitas fisik dengan tekanan darah pada pelajar SMA. Jurnal Gizi Klinik Indonesia. 2016;12(4):160-66. 